\title{
Białaczki z dużych ziarnistych limfocytów T i komórek naturalnej cytotoksyczności
}

\author{
Leukemias of T-cell large granular lymphocytes \\ and natural killers
}

\author{
Bożena Katarzyna Budziszewska \\ Klinika Hematologii, Instytut Hematologii i Transfuzjologii, Warszawa \\ Klinika Hematologii i Transfuzjologii, Centrum Medyczne Kształcenia Podyplomowego, Warszawa
}

\begin{abstract}
Streszczenie
Białaczki z dużych ziarnistych limfocytów (LGL) obejmuja biologicznie heterogenna grupe rzadkich nowotworów uktadu chtonnego wywodzacych sie z limfocytów T (T-LGL) lub z komórek naturalnej cytotoksyczności (NK-LGL). Wydaje sie, że biataczka T-LGL powstaje w wyniku dtugotrwatej stymulacji antygenowej, a przeżycie komórek LGL jest zwiqzane ze stała aktywacja antyapoptotycznych szlaków wewnatrzkomórkowych JAK/STAT, RAS/RAF/MEK/ERK, sfingolipidów i szlaków zewnatrzkomórkowych, takich jak FAS/FASL. Przebieg kliniczny może być rózny — indolentny lub agresywny. U większości pacjentów występuja objawy kliniczne pod postacia cytopenii, organomegalii o różnym nasileniu, często ze wspótistniejacymi chorobami autoimmunizacyjnymi, zwtaszcza reumatoidalnym zapaleniem stawów. Podstawa wspótczesnej diagnostyki biataczek LGL sa cytometria przeptywowa oraz badanie rearanżacji genów kodujacych receptor T-komórkowy. Większość pacjentów wymaga leczenia ze względu na cięzka powiktana zakażeniami neutropenię. Terapia jest oparta na leczeniu immunosupresyjnym; lekiem z wyboru w I linii jest metotreksat lub cyklofosfamid. Dotychczas nie opracowano standardów postępowania w biataczce T-LGL. Przewlekte biataczki T/NK-LGL maja charakter indolentny o korzystnym rokowaniu, natomiast biataczki agresywne T/NK-LGL sa gwattownie przebiegajacymi chorobami o ztym rokowaniu.
\end{abstract}

Słowa kluczowe: duże ziarniste limfocyty T, komórki naturalnej toksyczności, białaczka, choroby autoimmunizacyjne

Hematologia 2015; 6, 2: 155-167

\begin{abstract}
Leukemias of large granular lymphocytes (LGL) include a heterogeneous group of rare lymphoid malignancies derived from T cells (T-LGL) and natural killers (NK-LGL) T-LGL leukemia arises from long-term antigen stimulation and the survival of $L G L$ cells is associated with constitutive activation of anti-apoptotic intracellular pathways JAK/STAT, RAS/RAF/MEK/ERK, sphingolipids and extracellular FAS/FASL. The clinical course may be indolent or aggressive where majority of patients present clinical symptoms such as cytopenia, organomegaly and underlying autoimmune diseases; particularly rheumatoid arthritis. Diagnosing LGL leukemia is based on flow cytometry and T-cell receptor gene rearrangement. Most patients also require treatment for severe neutropenia complicated infections. T-LGL leukemia therapy is mainly immunosuppressive; the drug of
\end{abstract}

Adres do korespondencji: Bożena Katarzyna Budziszewska, Klinika Hematologii, Instytut Hematologii i Transfuzjologii, ul. Indiry Gandhi 14, 02-776 Warszawa, tel.: 223496 299, e-mail: kbudziszewska@ihit.waw.pl 
choice in the first line is methotrexate or cyclophosphamide but there are no established standards for treating LGL leukemia. Both chronic T/NK-LGL leukemias exhibit an indolent clinical course with a favorable prognosis, whereas aggressive T/NK-LGL leukemias are progressive diseases with poor prognosis.

Key words: large granular lymphocytes, natural killer cell, leukemias, autoimmune diseases

Hematologia 2015; 6, 2: 155-167

\section{Wprowadzenie}

Białaczki z dużych ziarnistych limfocytów (LGL, large granular lymphocytes) należą do rzadkich nowotworów układu chłonnego wywodzących się z limfocytów T (T-LGL) lub z komórek naturalnej cytotoksyczności (NK-LGL). Jest to heterogenna grupa schorzeń stanowiąca $2-3 \%$ białaczek $\mathrm{z}$ małych limfocytów. Zgodnie $\mathrm{z}$ klasyfikacją Światowej Organizacji Zdrowia (WHO, World Health Organization) wyróżnia się T-LGL o przebiegu indolentnym lub agresywnym, przewlekłe choroby limfoproliferacyjne $z$ komórek NK (CLPD-NK, chronic lymphoproliferative disorders of NK cells) i agresywną białaczkę NK-LGL. Najczęstszą postacią, stanowiącą $85 \%$ przypadków klonalnych chorób LGL, jest białaczka T-LGL $[1,2]$.

U zdrowych osób duże ziarniste limfocyty $\mathrm{T}$ stanowią 10-15\% jednojądrzastych komórek krwi obwodowej, tj. 0,1-0,3 G/1, i dzielą się na dwie populacje: dojrzałych, grasiczych cytotoksycznych limfocytów T CD8+CD3+ oraz komórek NK CD8+CD3-zdolnych do niszczenia komórek nowotworowych, komórek zakażonych przez wirusy lub wykazujących ekspresję allogenicznych antygenów głównego układu zgodności tkankowej [3]. W warunkach prawidłowej odpowiedzi na obecność patogenu następuje proliferacja dużych ziarnistych limfocytów T. Niekiedy jednak w odpowiedzi na stymulację antygenową proliferacja poliklonalnych cytotoksycznych limfocytów T CD8 + może być nadmierna i przedłużona, co prowadzi do przejściowej, odczynowej limfocytozy T-LGL. Opisano ją w przebiegu ostrych zakażeń, chorób autoimmunizacyjnych oraz powszechnego zmiennego niedoboru odporności (CVID, common variable immunodeficiency) [1, 4-6]. Reaktywna limfocytoza T-LGL powinna ulec normalizacji samoistnie lub w wyniku zastosowanej terapii choroby podstawowej w ciągu 6 miesięcy. Jeśli trwa dłużej niż 6 miesięcy, to rozpoznaje się przewlekłą limfocytozę T-LGL $[1,3]$.

Zarówno w przebiegu prawidłowych, jak i patologicznych odpowiedzi immunologicznych wśród
T-LGL mogą się pojawić również komórki klonalne CD8+CD3+, co określa się jako oligoklonalną lub monoklonalną limfocytoze T-LGL. Monoklonalna limfocytoza może być reakcją na obecność choroby autoimmunizacyjnej, infekcji wirusowych, przebytej splenektomii, przeszczepienie allogenicznych krwiotwórczych komórek macierzystych (allo-HSCT, allogeneic hematopoietic stem cell transplantation) lub innych transplantacji narządowych [7-12]. Co więcej, przewlekła klonalna limfocytoza CD8 + CD3 + występuje u osób starszych i nigdy nie rozwija się w białaczkę T-LGL $[11,13]$, choć fenotypowo komórki te nie różnią się od komórek białaczkowych [14]. Taka nienowotworowa proliferacja jest niekiedy określana jako stan przednowotworowy lub „klonopatia T-komórkowa o nieustalonym znaczeniu" (TCUS, T-cell clonopathy of undetermined significance), analogicznie do gammapatii monoklonalnej o nieustalonym znaczeniu (MGUS, monoclonal gammopathy of undetermined significance) $[15,16]$. W monoklonalnej limfocytozie TCUS, w przeciwieństwie do klasycznej białaczki T-LGL, nie występują objawy kliniczne ani inne zmiany w badaniu morfologicznym krwi.

\section{Białaczka z dużych ziarnistych limfocytów T}

Białaczkę $z$ dużych ziarnistych limfocytów T opisano w 1985 roku jako klonalną chorobę obejmującą szpik kostny i śledzionę [17], która może wystąpić w każdym wieku, nawet u dzieci, ale najczęściej chorują na nią osoby starsze około 60. roku życia. Średni okres pojawienia się objawów od momentu postawienia diagnozy to 37 miesięcy, a średni czas przeżycia pacjentów z białaczką $\mathrm{T}$ -LGL przekracza 10 lat [18-21].

\section{Etiopatogeneza}

Istnieje kilka hipotez dotyczących etiologii chorób nowotworowych wywodzących się z LGL. Jedną $z$ nich jest przewlekła stymulacja przez antygeny wirusowe, takie jak: ludzki wirus limfotropowy (HTLV-I, human T-cell lymphotrophic virus type I) 


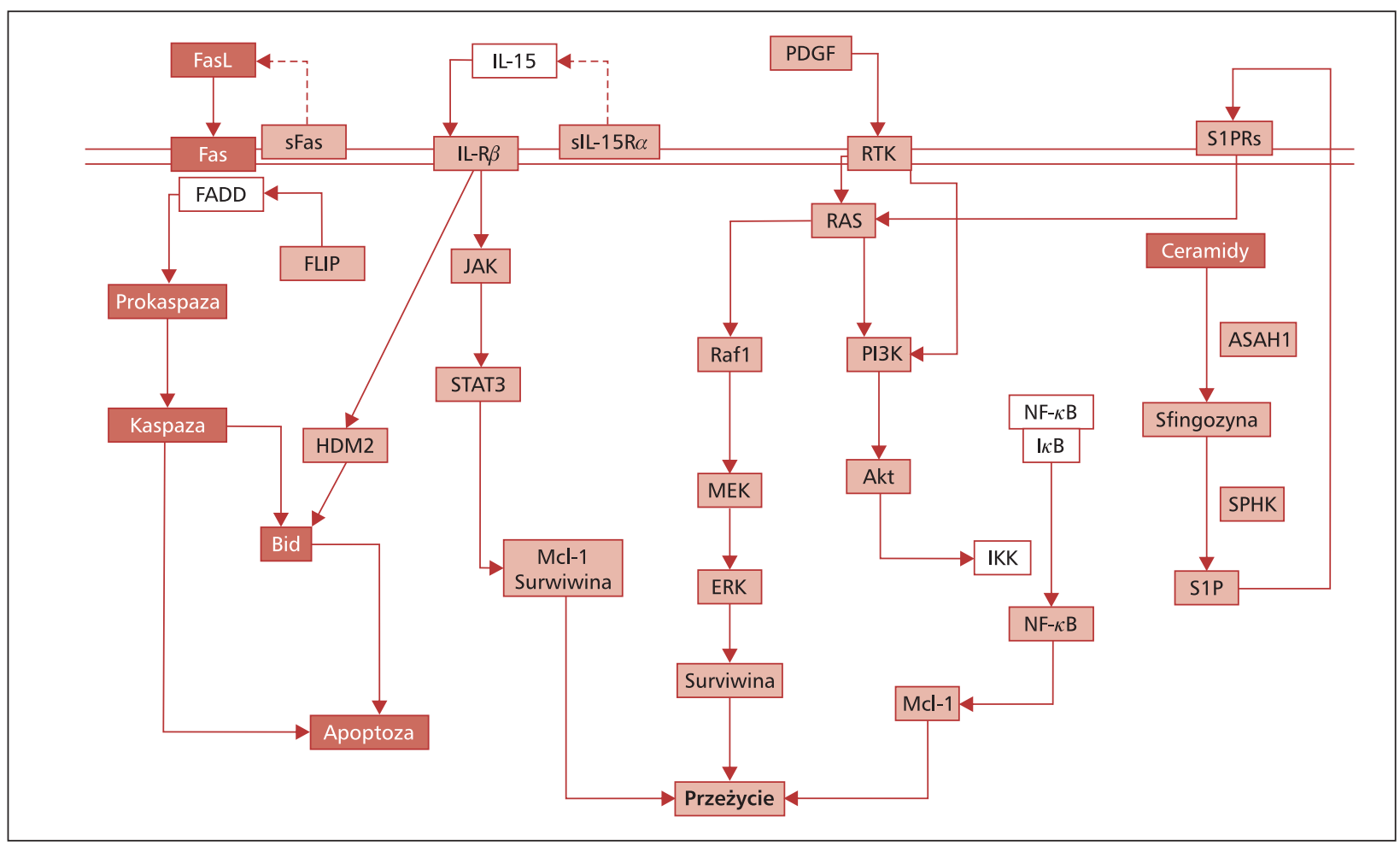

Rycina 1. Sieć wewnątrzkomórkowych szlaków sygnałowych biorących udział w patogenezie białaczki z dużych ziarnistych limfocytów T; nadrzędne i stale aktywne przekaźniki zaznaczono jasnym kolorem, sygnały hamujące — ciemnym kolorem, a na biało — przekaźniki, których status jest niezmieniony lub nie do końca poznany (wg [27]); ASAH — kwaśna ceramidaza; ERK — extracellular signal-regulated kinase; FasL — ligand Fas; IL — interleukina; MEK — kinaza białkowa aktywowana mitogenem; NF $\kappa$ B - czynnik transkrypcyjny NF kappa B; PDGF — płytkopochodny czynnik wzrostu; Pi3k - kinaza-3-fosfatydyloinozytolu; RTK — receptor kinazy tyrozynowej; S1P — fosforan sfingozyny 1; sFas - rozpuszczalny Fas

Figure 1. The signaling network underlying large granular lymphocytes T-cell leukemia pathogenesis. Up-regulated or constitutively active nodes are highlighted in light color; down-regulated or inhibited signals are in dark color; the states of withe nodes are unknown or unchanged compared with normal (acc. to [27]); ASAH - acid ceramidase; ERK — extracellular signal-regulated kinase; FasL — Fas ligand; IL — interleukin; MEK — mitogen-activated protein kinase; $\mathrm{NF} \kappa \mathrm{B}$ - nuclear factor kappa B; PDGF — platelet-derived growth factor; Pi3k — phosphatidylinositol 3 kinase; RTK — receptor tyrosine kinase; S1P — sphingosine-1-phosphate; sFas — soluble Fas

lub autoantygeny, która prowadzi do aktywacji i klonalnej ekspansji cytotoksycznych limfocytów T CD8+. U większości pacjentów wykazano obecność białka env p21e (BA 21) pochodzącego $z$ otoczki wirusa HTLV-I [22-25].

Istotnym mechanizmem uczestniczącym w patogenezie chorób wywodzących się z T-LGL jest zahamowanie apoptozy. Jak wcześniej wspomniano, podczas infekcji lub jakiejkolwiek stymulacji antygenowej dochodzi do gwałtownej proliferacji T-LGL, a ich liczba może się zwiększyć nawet 50 tys. razy. Po eliminacji antygenu komórki te są niszczone $\mathrm{w}$ mechanizmie tak zwanej aktywacji wywołującej śmierć komórki (AICD, activation-induced cell death). Jednak w białaczkowych komórkach T-LGL proces ten nie przebiega prawid- łowo i limfocyty $\mathrm{T}$ nie ulegają apoptozie. Istotną rolę odgrywają w nim liczne wewnątrzkomórkowe antyapoptotyczne szlaki sygnałowe ulegające aktywacji, co umożliwia przeżycie komórki. Należą do nich szlaki:JAK2/STAT3, RAS/RAF/MEK/ERK i SFK/PI3K/Akt oraz sfingolipidy [26, 27]. Sieć wewnątrzkomórkowych szlaków sygnałowych biorących udział w patogenezie białaczki T-LGL przedstawiono na rycinie 1 .

Wydaje się, że najistotniejszym czynnikiem warunkującym proliferację LGL, występującym u prawie wszystkich pacjentów, jest obecność aktywnej formy STAT3 - czynnika transkrypcyjnego szlaku sygnałowego JAK/STAT, który kontroluje proliferację i apoptozę wielu komórek, jak również procesy angiogenezy i odpowiedzi 
immunologicznej. Przetrwała aktywacja STAT3, między innymi przy udziale interleukiny 6 (IL-6), jest odpowiedzialna za proliferację limfocytów $\mathrm{T}$ poprzez zahamowanie apoptozy niezależnej od BCL-2 [28]. U 40\% pacjentów z białaczką T-LGL przyczyną stałej aktywacji czynnika transkrypcyjnego STAT3 jest obecność somatycznych mutacji genu $S T A T 3$, ale również inne mutacje takich genów, jak PTPRT, BCL11B, SLIT2 i NRP1, które mogą być związane $z$ aktywacją STAT3 $[29,30]$. Stwierdzenie somatycznych mutacji, zwłaszcza genu STAT3, może stanowić istotne narzędzie w różnicowaniu „prawdziwej” białaczki T-LGL i odczynowej monoklonalnej limfocytozy T-LGL. Ponadto specyficzne inhibitory STAT3, takie jak na przykład OPB-3112 [31], wprowadzane do badań klinicznych w leczeniu innych nowotworów hematologicznych mogą się stać również terapią celowaną w białaczce T-LGL [29].

Białaczkowe komórki T-LGL są także oporne na apoptozę zależną od szlaku sygnałowego FAS/ligand FAS (FAS/FASL, Fas ligand). W warunkach fizjologicznych interakcja FASL $i$ jego receptora powoduje aktywację szlaków apoptotycznych poprzez tworzenie kompleksu sygnałowego indukującego śmierć komórki (DISC, death-inducing signaling complex) $\mathrm{w}$ procesie AICD. W komórkach T-LGL stwierdzono nadekspresję białek hamujących kompleks DISC oraz obecność rozpuszczalnego receptora FAS (sFAS, soluble FAS), co prowadzi do zahamowania apoptozy za pośrednictwem tego szlaku, mimo wysokiej ekspresji powierzchniowego receptora FAS/FASL oraz nieobecności mutacji genu receptora $F A S[32,33]$. Upośledzenie zależnej od Fas śmierci komórki przyczynia się do rozwoju białaczki T-LGL.

W komórkach białaczkowych T-LGL stwierdzono również stałą aktywację antyapoptotycznych szlaków sygnałowych RAS/RAF/MEK/ERK, PI3K/AKT i związanego $z$ nimi czynnika transkrypcyjnego kappa B (NF- $\kappa \mathrm{B}$, nuclear factor kappa B), co prowadzi do zahamowania apoptozy i zwiększenia przeżywalności monoklonalnych limfocytów T [27].

Jako nadrzędne przekaźniki dla tych szlaków sygnałowych zidentyfikowano interleukinę 15 (IL-15) i płytkopochodny czynnik wzrostu (PDGF, platelet-derived growth factor). Interleukina 15, należąca do rodziny IL-2, powoduje ekspresję białek rodziny BCL-1 (BCL-2 i BCL-XL) i, poprzez aktywację szlaków sygnałowych, podtrzymuje populację zarówno prawidłowych komórek pamięci CD8+ i komórek NK, jak i białaczkowych komórek T-LGL $[13,34]$. Wykazano, że podjednostka rozpuszczalnego receptora IL-15R $\alpha$ ma regulujący wpływ na komórki jednojądrzaste krwi obwodowej pacjentów $z$ białaczką T-LGL. Wyższy poziom ekspresji IL-15R $\alpha$ prowadzi do obniżenia progu odpowiedzi na IL-15, a w konsekwencji - do znacznie większej proliferacji komórek białaczkowych T-LGL pod wpływem egzogennej IL-15, w porównaniu z komórkami prawidłowymi [35]. Płytkopochodny czynnik wzrostu jest najsilniejszym czynnikiem wzrostu dla komórek T i NK w białaczce T/NK-LGL. Obok IL-15 odgrywa kluczową rolę w patogenezie w białaczce T-LGL, regulując przeżywalność komórek poprzez szlaki sygnałowe PI3K-AKT i MEK/ERK [36].

W patogenezie białaczki T-LGL uczestniczą również sfingolipidy odgrywające znaczącą rolę $\mathrm{w}$ procesach proliferacji, apoptozy i migracji komórek. O losie komórki decyduje nie tyle ilość sfingolipidów, co równowaga między ceramidami proapoptotycznymi, takimi jak sfingozyna, a antyapoptotycznymi, takimi jak fosforan sfingozyny 1 (S1P-sfingosine-1 phosphate). Analiza molekularna ujawnia, że w komórkach białaczkowych T-LGL równowaga ta zostaje zaburzona na korzyść czynników antyapoptotycznych [37].

\section{Definicja}

Białaczka $z$ dużych ziarnistych limfocytów $\mathrm{T}$ charakteryzuje się obecnością przetrwałych (> 6 mies.) limfocytów T-LGL, których liczba we krwi obwodowej wynosi 2-20 G/1 [2]. Należy jednak podkreślić, że 25-30\% u pacjentów $z$ nowo zdiagnozowaną chorobą liczba T-LGL wynosi mniej niż 0,5 G/1, a według Prochorec i wsp. ponad połowa chorych na białaczkę T-LGL i chorobę autoimmunizacyjną nie spełniała ilościowego kryterium rozpoznania dotyczącego liczby T-LGL, co interpretowano jako klonalną reakcję na chorobę podstawową $[38,39]$. Obecnie, w dobie badań molekularnych, białaczkę T-LGL rozpoznaje się nawet w przypadku stwierdzenia klonalnej limfocytozy T-LGL między 0,4 a 2 G/l, jeśli towarzyszą jej objawy kliniczne $\mathrm{i} /$ lub inne zmiany morfologiczne krwi $[38,40]$.

\section{Objawy kliniczne}

W przebiegu klinicznym białaczki T-LGL dominuje limfocytoza T-LGL, jak wspomniano, nawet do $20 \mathrm{G} / 1$ ze wspólistniejącą neutropenią, w $50 \%$ przypadków ciężką, z liczbą neutrofili poniżej 0,5 G/l. U około połowy pacjentów występuje niedokrwistość, a u 5-35\% z nich może być zależna od przetoczeń koncentratu krwinek czerwonych (kkcz). U 20\% chorych występuje małopłytkowość. Cytopenii może towarzyszyć splenomegalia i hepatomegalia, rzadziej limfadenopatia. Typowym 
Tabela 1. Częstość występowania objawów klinicznych u pacjentów z białaczką z dużych ziarnistych limfocytów T (źródło [4])

Table 1. The incidence of clinical symptoms in patients with leukemia of T-cell large granular lymphocytes (source [4])

\begin{tabular}{lc}
\hline Objawy & $\begin{array}{c}\text { Częstość } \\
\text { występowania (\%) }\end{array}$ \\
\hline Neutropenia & $65-85$ \\
Przewlekła niedokrwistość & $20-60$ \\
Splenomegalia & $15-56$ \\
Hepatomegalia & 50 \\
Objawy ogólne & $20-40$ \\
Nawracające infekcje bakteryjne & $10-20$ \\
\hline
\end{tabular}

objawem są nawracające infekcje bakteryjne, dotyczące głównie skóry, śluzówek i układu oddechowego. Część pacjentów zgłasza objawy ogólne pod postacią zmęczenia, wzmożonej potliwości nocnej, stanów podgorączkowych i zmniejszenia masy ciała [1, 3, 4, 41]. Częstość występowania objawów klinicznych przedstawiono w tabeli 1.

U pacjentów $z$ białaczką T-LGL często są obecne dodatnie odczyny serologiczne, co wiąże się ze wspólistnieniem chorób autoimmunizacyjnych. W tabeli 2 przedstawiono nieprawidłowości serologiczne spotykane $\mathrm{u}$ pacjentów $\mathrm{z}$ białaczką T-LGL [3, 16, 42].

Do najczęściej występujących chorób autoimmunizacyjnych u pacjentów $z$ klonalnymi chorobami limfocytów T-LGL należą reumatoidalne zapalenie stawów (RA, rheumatoid arthritis) (25-30\%) i zespół Felty'ego (40\%) [43-45]. Opisano przypadki białaczki T-LGL $z$ towarzyszącym zespołem Evansa, zespołem Sjögrena, zapaleniem tarczycy typu Hashimoto, chorobą Gravesa-Basedowa, zespołem Cushinga, nadczynnością przytarczyc, stwardnieniem rozsianym, wrzodziejącym zapaleniem jelita grubego, łuszczycą oraz nawracającym zapaleniem naczyniówki $[1,3,7,16,21]$. Niedokrwistość, małopłytkowość i neutropenia występujące u pacjentów $z$ białaczką T-LGL mają również komponentę immunologiczną związaną $z$ obecnością przeciwciał [41].

Białaczka T-LGL jest również najczęstszą przyczyną wybiórczej aplazji czystoczerwonokrwinkowej (PRCA, pure red cells aplasia) u dorosłych i występuje u 8-19\% pacjentów [3, 46, 47]. Dlatego ocena obecności klonalnych limfocytów T-LGL powinna być rutynowo przeprowadzona u pacjentów $z$ PRCA, nawet jeśli istnieją inne przyczyny aplazji, takie jak infekcja parvowirusem
Tabela 2. Nieprawidłowości biochemiczne i serologiczne oraz częstość ich występowania u pacjentów z białaczką z dużych ziarnistych limfocytów (źródła $[3,16,42]$ )

Table 2. Biochemical and serological abnormalities and their prevalence in patients with large granular lymphocytes leukemia (sources $[3,16,42]$ )

\begin{tabular}{lc}
\hline $\begin{array}{l}\text { Nieprawidłowości biochemiczne } \\
\text { i serologiczne }\end{array}$ & $\begin{array}{c}\text { Częstość } \\
\text { występowania (\%) }\end{array}$ \\
\hline $\begin{array}{l}\text { Podwyższone stężenie } \\
\beta_{2} \text {-mikroglobuliny }\end{array}$ & 70 \\
$\begin{array}{l}\text { Czynnik reumatoidalny } \\
\text { (RF, rheumatoid factor) }\end{array}$ & 61 \\
Przeciwciała przeciwjądrowe & 44 \\
Hipergammaglobulinemia & 38 \\
poliklonalna & \\
Podwyższona aktywność LDH & 33 \\
Przeciwciała przeciwpłytkowe & 25 \\
Przeciwciała & 20 \\
przeciwgranulocytarne & 15 \\
Gammapatia monoklonalna & 14 \\
Dodatni odczyn Coombsa & $B D$ \\
Krążące kompleksy \\
immunologiczne
\end{tabular}

B19 (PV B19) czy grasiczak. Infekcja PV B19 znacznie szybciej rozwija się u pacjentów $z$ białaczką T-LGL [48, 49]. Wydaje się, że niszczenie prekursorów krwinek czerwonych przez cytotoksyczne limfocyty T odgrywa główną rolę $\mathrm{w}$ mechanizmie rozwoju PRCA u tych chorych [3, 7]. Białaczkę T-LGL opisywano również u pacjentów $z$ anemią aplastyczną i zespołem mielodysplastycznym [16, $50,51]$. Przetrwała stymulacja antygenowa prowadząca do proliferacji klonalnych komórek T-LGL może być również czynnikiem patogenetycznym nowotworów B-komórkowych, takich jak: chłoniaki z małych limfocytów B, białaczka włochatokomórkowa, chłoniak limfoplazmocytowy, szpiczak plazmocytowy, chłoniaki strefy brzeżnej, chłoniak Hodgkina [52-54]. Volkheimer i wsp. [55] wykazali, że u $18 \%$ chorych na białaczkę T-LGL rearanżacji genów kodujących receptor T-komórkowy (TCR, T-cell receptor) towarzyszą rearanżacje genów kodujących części zmienne łańcuchów lekkich kappa i lambda immunoglobulin, świadczące o monoklonalności limfocytów B.

\section{Badania diagnostyczne}

Podstawą współczesnej diagnostyki klonalnych chorób T-LGL są badania immunofenoty- 
Tabela 3. Charakterystyka immunofenotypowa prawidłowych i nowotworowych dużych ziarnistych limfocytów T i komórek naturalnej cytotoksyczności

Table 3. Immunophenotyping characteristics of normal and leukemic T-cell large granular lymphocytes and natural killers

\begin{tabular}{ll}
\hline Typ białaczki & Immunofenetyp \\
\hline Prawidłowe limfocyty T-LGL & $\mathrm{CD} 2+\mathrm{CD} 3+\mathrm{CD} 4-\mathrm{CD} 5+\mathrm{CD} 7+\mathrm{CD} 8+\mathrm{CD} 16-\mathrm{CD} 56-\mathrm{TCR} \alpha \beta+\mathrm{TCR} \gamma \delta-$ \\
Białaczka T-LGL: & $\mathrm{CD} 3+\mathrm{TCR} \alpha \beta+\mathrm{CD} 8+\mathrm{CD} 57+\mathrm{CD} 16+$ \\
- postać indolentna & $\mathrm{CD} 3+\mathrm{TCR} \alpha \beta+\mathrm{CD} 8+\mathrm{CD} 56+\mathrm{CD} 16+$ \\
- postać agresywna & $\mathrm{CD} 3-\mathrm{CD} 56+\mathrm{CD} 16+$ \\
Agresywna białaczka NK-LGL & $\mathrm{CD} 3-\mathrm{CD} 56+\mathrm{CD} 16+$ \\
Przewlekła limfocytoza z komórek NK & (leukemia of T-cell large granular lymphocytes) - białaczka z dużych ziarnistych limfocytów T; NK-LGL (leukemia of
\end{tabular}

natural killers large granular lymphocytes) - białaczka z dużych ziarnistych limfocytów naturalnej cytotoksyczności

powe metodą cytometrii przepływowej i badania molekularne potwierdzające klonalną rearanżację TCR. Różnicowanie na podstawie badania morfologicznego reaktywnych, lagodnych komórek LGL od białaczkowych jest niemożliwe. W ocenie morfologicznej rozmazu krwi obwodowej i szpiku widoczne są duże ('średnica 15-18 $\mu \mathrm{m}$ ), jednojądrzaste komórki $z$ okrągłym, wypełnionym skondensowaną, dojrzałą chromatyną, jądrem oraz zwiększoną ilością bladoniebieskiej cytoplazmy, w której są widoczne przypadkowo rozłożone, azurofilne ziarnistości. Jednak nie wszystkie komórki T-LGL mają typową morfologię i mogą nie zawierać ziarnistości $[39,56]$. Trepanobiopsja szpiku kostnego ujawnia dyskretne, słabo barwiące się hematoksyliną i eozyną śródmiąższowe i linijne wewnątrzzatokowe nacieki z limfocytów T lub ich małe skupiska [17]. Loughran i wsp. [1, 19] uważają nawet, że biopsja szpiku kostnego nie jest konieczna w diagnozowaniu białaczki T-LGL. Jednak wprowadzenie badań immunohistochemicznych $\mathrm{w}$ diagnostyce proliferacji komórek T-LGL zdecydowanie poprawiło ich identyfikację i pozwoliło na wykrycie nacieków w szpiku kostnym u ponad $85 \%$ pacjentów $[1,17]$. Stwierdzenie ekspresji CD3 i CD8 na tych limfocytach oraz obecność w ich cytoplazmie ziarnistości, w których wykrywa się takie markery, jak granzym B, TIA-1 (TIA-1, T-cell intracellular antigen 1) i perforynę, wydaje się specyficzne dla białaczki T-LGL [57, 58]. Niemniej jednak nie stwierdzono korelacji między wielkością nacieku komórek T-LGL w szpiku a stopniem cytopenii czy ciężkością objawów klinicznych [1].

Badanie immunofenotypowe metodą cytometrii przepływowej jest rekomendowaną metodą identyfikacji białaczkowych komórek T-LGL [1, 3]. Prawidłowe komórki T-LGL charakteryzują się fenotypem CD2 + CD3+CD4-CD5+CD7+CD8+CD16-CD56- TCR $\alpha \beta+$ i TCR $\gamma \delta-$. Komórki nowotworowe T-LGL mają również fenotyp doj- rzałych komórek T lub NK, ale w $80 \%$ wykazują nieprawidłową ekspresję antygenów pan-T-komórkowych, na przykład CD5 czy CD7, oraz obecność antygenów komórek NK, takich jak CD16+ (w 80\%) i CD57+ (100\%) [19, 59, 60]. Antygen CD57 jest charakterystycznym markerem białaczki T-LGL, co sugeruje, że białaczkowe limfocyty T-LGL pochodzą z CD57(-) komórek T pamięci, które nabywają antygen CD57 jako komórki efektorowe [61]. Większość białaczkowych komórek wykazuje $\mathrm{TCR} \alpha \beta+$, a przypadki $\mathrm{TCR} \gamma \delta+$ rokują gorzej. Najpowszechniejsze immunofenotypy białaczek T-LGL i NK-LGL przedstawiono w tabeli 3 [1].

Zaburzenia cytogenetyczne w białaczce T-LGL występują jedynie w około 10\% przypadków; mogą się pojawić aberracje chromosomalne, takie jak: inwersja 12p, 14q, delecja 5q, trisomie chromosomów 3, 8, 14 [1, 62].

Wykazanie monoklonalności limfocytów T-LGL stanowi jedno $z$ podstawowych kryteriów rozpoznania proliferacji komórek T-LGL i polega na badaniu klonalności TCR. Receptor ten, obecny na powierzchni limfocyta $\mathrm{T}$, jest glikoproteiną składającą się $z$ dwóch łańcuchów polipeptydowych $\alpha$ i $\beta$, a w mniej niż $10 \%$ przypadków są to łańcuchy $\gamma$ i $\delta$. Jest on zdolny do swoistego rozpoznania antygenu, a w połączeniu z glikoproteiną CD3 nabywa zdolności przekazywania sygnału i aktywacji limfocyta $\mathrm{T}$ [63]. W okresie rozwoju i dojrzewania limfocytów T dochodzi do rearanżacji genów kodujących TCR, w wyniku czego powstają populacje limfocytów T $z$ unikatową molekularną sekwencją nukleotydów. Ocenia się, że w wyniku rearanżacji może powstać nawet $10^{18}$ unikatowych TCR $[1,64]$. Nadmierna proliferacja jednej tylko populacji limfocytów T $z$ jednakową rearanżacją TCR prowadzi do rozrostu monoklonalnego.

Klonalność komórek T-LGL jest rutynowo badana metodą reakcji łańcuchowej polimerazy (PCR, polymerase chain reaction). Chociaż jej czu- 
łość jest mniejsza niż metody Southern blot i wynosi $70-80 \%$, to jest mniej czasochłonna i nie wymaga dużej ilości dobrego jakościowo DNA [63]. Klonalną rearanżację TCR można również potwierdzić, wykorzystując metodę cytometrii przepływowej $z$ użyciem przeciwciał monoklonalnych rozpoznających fragmenty łańcuchów $\beta$ regionów zmiennych $\left(\mathrm{V}_{\beta}\right)$ TCR. Czułość tej metody wynosi około $80 \%$ i jest porównywalna $z$ czułością metody PCR [3]. Jej zaletą jest krótki czas, w jakim uzyskuje się potwierdzenie klonalności, i możliwość oceny podtypów łańcuchów $\mathrm{V}_{\beta}$. Choć nie opisano specyficznych podtypów $\mathrm{V}_{\beta}$ związanych z białaczką T-LGL, to opisano częstsze występowanie podtypu $\mathrm{V}_{\beta} 6$ [65].

Komórki białaczkowe T-LGL wykazują również nieprawidłową ekspresję receptorów immunoglobulinopodobnych (KIR, killer cell immunoglobulin-like receptors), aktywujących komórki NK. Dzięki nim komórki NK rozpoznają antygeny zgodności tkankowej (MCH, major histocompatibility complex) I klasy i biorą udział w reakcji własnej tolerancji na antygeny. $Z$ użyciem przeciwciał CD158 można wykazać ekspresję monoklonalnych receptorów KIR u ponad połowy pacjentów $z$ białaczką T-LGL [66-68].

W różnicowaniu białaczki T-LGL należy uwzględnić białaczkę włochatokomórkową, ubogokomórkową postać ostrej białaczki limfoblastycznej, anemię aplastyczną, hipoplastyczny zespó1 mielodysplastyczny, nocną napadową hemoglobinurię i immunologiczną agranulocytozę.

\section{Leczenie}

Nie ma standardów leczenia białaczki T-LGL. Ze względu na rzadkie występowanie tych chorób prowadzenie badań prospektywnych jest trudne. Większość danych pochodzi z badań retrospektywnych i licznych opisów przypadków. Największe opublikowane retrospektywne badanie Bareau i wsp. [20] obejmowało grupę 229 pacjentów leczonych w latach 1999-2007 w 35 ośrodkach we Francji. Przedstawiono w nim kliniczną i biologiczną charakterystykę pacjentów $z$ białaczkami T/NK-LGL oraz wyniki odpowiedzi na zastosowane leczenie (opisane poniżej przy omawianiu poszczególnych rodzajów terapii).

Ze względu na patogenezę choroby terapią podstawową pozostaje leczenie immunosupresyjne. Leki immunosupresyjne stosuje się w monoterapii lub w skojarzeniu. Zarówno białaczka T-LGL, jak i białaczka $z$ komórek NK zwykle ma przewlekły przebieg kliniczny. Schemat postępowania przedstawiono na rycinie 2 .

U pacjentów bez objawów najlepszym postępowaniem jest obserwacja (watch and wait). Wskazaniami do leczenia są:
- ciężka neutropenia (bezwzględna liczba neutrofili [ANC, absolute neutrophil count] $<0,5 \mathrm{G} / 1$ );

- umiarkowana neutropenia (ANC 0,5-1,0 G/1) Z nawracającymi infekcjami;

- objawowa lub wymagająca przetoczeń kkcz niedokrwistość;

- współistniejące choroby autoimmunizacyjne wymagające leczenia, najczęściej RA.

\section{Leczenie immunosupresyjne}

Metotreksat (MTX, methotrexate) jest lekiem I linii w białaczce T-LGL; zalecana dawka to $5-10 \mathrm{mg} / \mathrm{m}^{2}$ powierzchni ciała $\mathrm{raz} \mathrm{w}$ tygodniu [41, 69]. W badaniu Bareau i wsp. [20] odsetek wszystkich odpowiedzi u chorych na T/NK-LGL leczonych MTX wynosił 55\%, a czas do uzyskania odpowiedzi - 2-12 tygodni. Niestety, u znaczącego odsetka chorych obserwowano nawrót choroby $\mathrm{w}$ trakcie terapii, a neutropenia pojawiała się ponownie nawet u pacjentów, którzy uzyskali całkowitą remisję molekularną [20]. Czas leczenia MTX nie został zdefiniowany. Wiadomo, że u pacjentów, którzy nie uzyskują przynajmniej częściowej odpowiedzi po 4 miesiącach, leczenia nie należy kontynuować. Natomiast u chorych $\mathrm{z}$ częściową lub całkowitą odpowiedzią, którzy dobrze tolerują MTX, leczenie należy prowadzić przez czas nieokreślony, do wystąpienia nawrotu/progresji choroby lub toksyczności MTX. W trakcie leczenia MTX należy przede wszystkim monitorować czynność wątroby i płuc [70].

Cyklofosfamid (Cy) jest stosowany w monoterapii u pacjentów $\mathrm{z}$ białaczkami $\mathrm{T}$ i NK, $\mathrm{w}$ dawce 50-100 mg/dobę doustnie - szczególnie w przypadkach ze współistniejącą PRCA [40, 41, 71]. W badaniu Bareau i wsp. [20] lączny odsetek odpowiedzi był nawet większy niż w przypadku MTX i wynosił $65 \%$. Warto odnotować, że 11 z 15 pacjentów, którzy nie zareagowali na leczenie MTX, uzyskało odpowiedź po podaniu Cy [20]. Lamy i wsp. [41] uważają, że leczenie I linii za pomocą Cy można prowadzić do 6 lub 12 miesięcy u chorych, u których uzyskuje się odpowiedź.

Cyklosporyna A (CsA) może być lekiem alternatywnym dla MTX i Cy w leczeniu I linii, zwłaszcza u pacjentów $z$ niedokrwistością lub PRCA oraz u pacjentów $z$ ekspresją antygenu HLA DR4, który obserwuje się u 32\% osób z białaczką T-LGL i 90\% chorych ze wspólistniejącym RA. Jednak większość autorów proponuje CsA jako II linię leczenia, ponieważ nie powoduje ona eradykacji komórek białaczkowych. Odsetek odpowiedzi jest bardzo różny w poszczególnych badaniach i nierzadko $\mathrm{w}$ trakcie terapii dochodzi do utraty odpowiedzi [20, 40, 41, 69, 71-73]. 


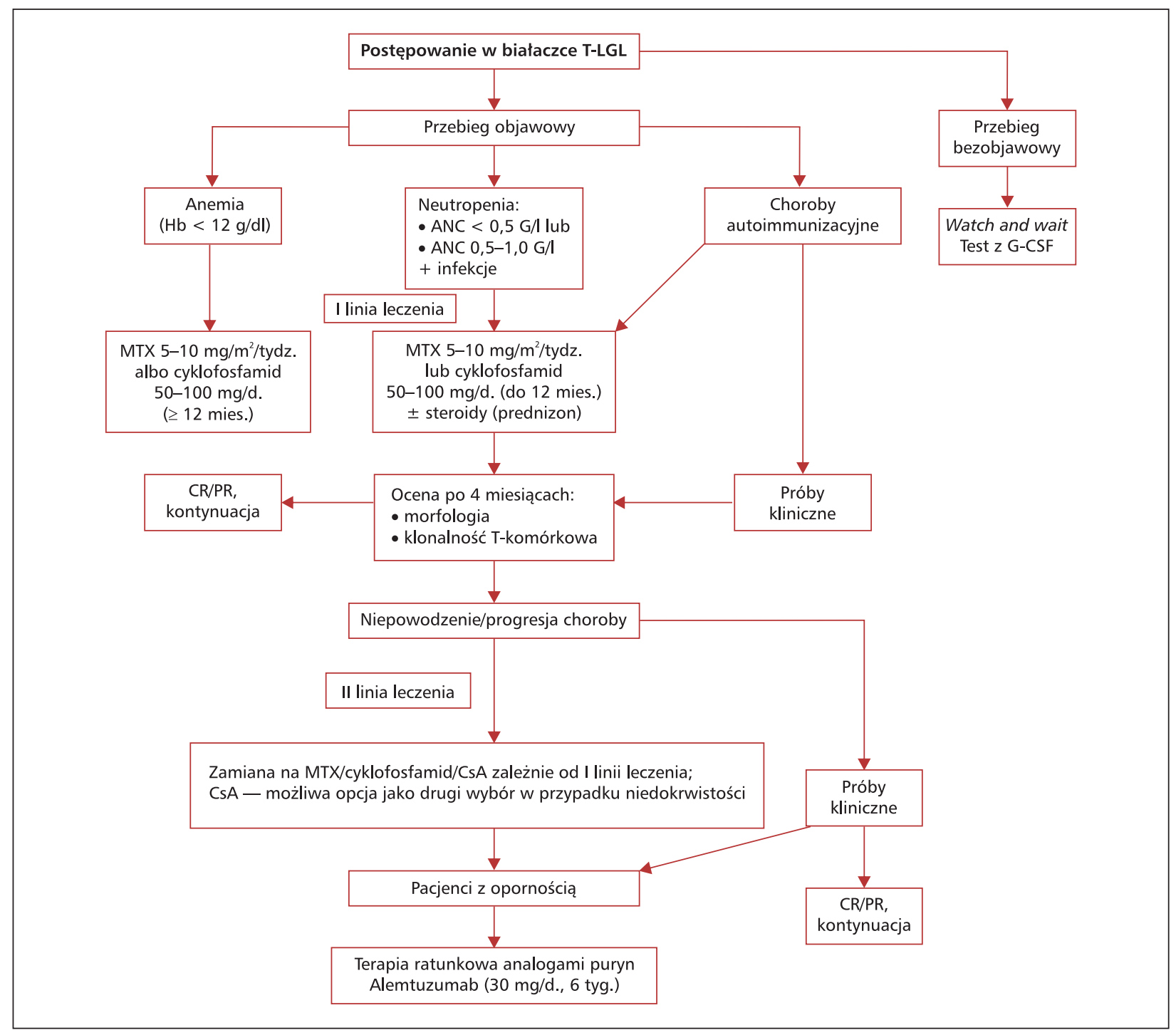

Rycina 2. Schemat postępowania u pacjentów z białaczką z dużych ziarnistych limfocytów T (T-LGL); Hb - hemoglobina; ANC — bezwzględna liczba neutrofili; MTX — metotreksat; G-CSF — czynnik stymulujący tworzenie kolonii granulocytów; CR - całkowita remisja; PR - częściowa remisja; CsA - cyklosporyna A

Figure 2. Diagram of the treatment patients with T-cell large granular lymphocytes (T-LGL) leukemia; Hb - hemoglobin; ANC - absolute neutrophil count; MTX - methotrexate; G-CSF — granulocyte-colony stimulating factor; $\mathrm{CR}$ - complete remission; $\mathrm{PR}$ - partial remission; CsA - cyclosporine A

\section{Steroidoterapia}

Zastosowanie steroidów w leczeniu chorych na białaczkę T-LGL nie przyniosło spodziewanych rezultatów. Nie wykazano długotrwałego efektu ani w korygowaniu neutropenii, ani zmniejszaniu liczby komórek białaczkowych [20], choć prednizon może ograniczyć objawy, zwłaszcza te związane $z$ RA, lub przejściowo poprawić liczbę neutrofili. Steroidoterapię należy stosować głównie w celu uzyskania szybkiej poprawy wskaźników morfologicznych lub zmniejszenia nasilenia objawów ogólnych w ocze- kiwaniu na efekt włączonych jednoczasowo innych leków immunosupresyjnych.

\section{Czynniki wzrostu}

Czynnik stymulujący tworzenie kolonii granulocytów (G-CSF, granuclocyte-colony stimulating factor) może indukować przejściowy wzrost neutrofilii u pacjentów z białaczką T-LGL, ale znaczna część pacjentów pozostaje oporna lub słabo reaguje na podanie G-CSF. Może być on stosowany w okresie oczekiwania na efekt działania leków im- 
munosupresyjnych lub u gorączkujących pacjentów $z$ neutropenią $\mathrm{w}$ okresie antybiotykoterapii. Jednak trzeba pamiętać, że u pacjentów $z$ białaczką T-LGL podanie G-CSF może powodować zwiększenie splenomegalii i nasilenie dolegliwości stawowych [71]. Niektórzy autorzy [27, 41] polecają wykonanie u pacjentów $z$ bezobjawową neutropenią testu $z$ jednorazowym podaniem G-CSF $w$ celu oceny potencjalnej mobilizacji mieloidalnych komórek prekursorowych. U pacjentów $z$ pozytywnym wynikiem testu $\mathrm{z}$ zastosowaniem G-CSF, w przypadku wystąpienia gorączki neutropenicznej, podawanie czynnika wzrostu może być skuteczne [27].

Erytropoetynę (EPO) można stosować łącznie $z$ leczeniem immunosupresyjnym. U pacjentów leczonych CsA, którzy uzyskali częściową remisję (PR, partial remission), dodanie EPO może spowodować konwersję do całkowitej remisji (CR). Brakuje jednak danych, jakie wyjściowe stężenie EPO obserwowano u tych pacjentów [72]. W badaniu Bareau i wsp. [20] jedynie u 2 z 7 chorych uzyskano przejściową odpowiedź na leczenie EPO. Erytropoetyna nie jest również rekomendowana w przypadku PRCA u pacjentów z białaczką T-LGL.

\section{Analogi puryn}

Opublikowano pojedyncze prace dotyczące zastosowania fludarabiny jako leczenia I linii lub u chorych opornych na leki immunosupresyjne. Odsetek odpowiedzi hematologicznych i molekularnych sięgał $80 \%$, a toksyczność była akceptowalna. Uzyskane remisje są długotrwałe, nawet kilkuletnie. Należy jednak pamiętać, że opublikowane prace dotyczą kilku chorych, dlatego są konieczne prospektywne badania kliniczne, w których zostanie ocenione zastosowanie analogów puryn u większej liczby chorych [41, 74-77].

\section{Inne metody leczenia}

Alemtuzumab, humanizowane monoklonalne przeciwciało anty-CD52, stosowano u pacjentów z opornymi na leczenie białaczkami. Chociaż odsetek odpowiedzi wynosił $60 \%$, to zastosowanie alemtuzumabu ogranicza nie tylko znaczna toksyczność leku, ale również słabsza ekspresja CD52 na białaczkowych komórkach T-LGL w porównaniu z prawidłowymi limfocytami CD8 + [78-80].

Chemioterapia zgodnie ze schematami CHOP-like (cyklofosfamid, doksorubicyna, winkrystyna, prednizon) powinna być stosowana jedynie w przypadkach białaczki opornej na leczenie immunosupresyjne lub w postaciach agresywnych. Ogólnie stosowanie małych dawek chemioterapeu- tyków wydaje się bardziej efektywne niż sekwencyjne podawanie dużych dawek [41].

U kilku chorych przeprowadzono allo-HSCT, ale procedura ta nie odgrywa istotnej roli w leczeniu. Splenektomia może być opcją terapeutyczną zwłaszcza dla pacjentów $z$ neutropenią, niedokrwistością hemolityczną i splenomegalią, ale w ostatnio opublikowanych badaniach efekty tego leczenia nie okazały się dobre [81].

\section{Nowe leki}

Próba leczenia 8 chorych na białaczkę T-LGL tipifarnibem, inhibitorem tranferazy farnezylowej, w badaniu II fazy RI15077 nie przyniosła efektu w postaci osiągnięcia odpowiedzi hematologicznej [27]. Ostatnio opublikowano opisy 2 pacjentów z długotrwałą remisją białaczki T-LGL i ze współistniejącym RA po leczeniu rytuksymabem. U obu przypadkach wskazaniem do zastosowania rytuksymabu było RA [82].

Ocena odpowiedzi na leczenie powinna się odbyć po 4 miesiącach od momentu rozpoczęcia terapii. Całkowita remisja hematologiczna jest zdefiniowana jako normalizacja wskaźników morfologicznych krwi obwodowej, tj. stężenie $\mathrm{Hb}$ powyżej $12 \mathrm{~g} / \mathrm{dl}$, liczba płytek krwi powyżej $150 \mathrm{G} / \mathrm{l}$, liczba neutrofili przekraczająca 1,5 G/l, liczba limfocytów poniżej $4 \mathrm{G} / 1$ oraz prawidłowa liczba komórek T-LGL potwierdzona w badaniu metodą cytometrii przepływowej. Całkowitą remisję molekularną rozpoznaje się wtedy, gdy brakuje klonalnych limfocytów T w badaniu metodą PCR.

\section{Agresywna białaczka T-LGL}

Agresywna białaczka T-LGL występuje bardzo rzadko i różni się znacząco od białaczki T-LGL przebiegiem klinicznym, leczeniem i prognozą. Dotyczy młodszych pacjentów — ze średnią wieku 41 lat. Ze względu na małą liczbę opisanych przypadków nie wyszczególniono jej dotychczas w klasyfikacji WHO jako odrębnej jednostki klinicznej. Patogeneza tej postaci nie jest znana; nie wiadomo również, czy choroba rozwija się de novo, czy też jest klonalną ewolucją indolentnej postaci białaczki T-LGL [83-85]. Matutes i wsp. [85] opisali przypadek transformacji Richtera indolentnej postaci białaczki T-LGL po 11 latach od momentu postawienia diagnozy.

Kliniczny przebieg agresywnej białaczki T-LGL charakteryzują występowanie nasilonych objawów ogólnych, hepatosplenomegalii, limfadenopatii, we krwi obwodowej obserwuje się znacznie wyższą liczbę klonalnych limfocytów T-LGL, często powyżej $10 \mathrm{G} / 1$, niedokrwistość w różnym stopniu 
nasilenia, małopłytkowość i oporność na leczenie. Podstawą rozpoznania jest obecność charakterystycznego immunofenotypu komórek T-LGL, tj. CD3+CD8+CD16+CD56+TCR $\alpha \beta+$ lub rzadziej TCR $\gamma \delta+$. Od postaci indolentnej agresywną białaczkę T-LGL odróżnia ekspresja antygenu CD56 na komórkach białaczkowych [83-85]. Rokowanie u pacjentów $\mathrm{z}$ tą postacią białaczki T-LGL jest złe, jeśli chorobę leczy się konwencjonalną chemioterapią. Mimo niewielkiej liczby opublikowanych przypadków wydaje się, że lepsze wyniki przynosi stosowanie intensywnej chemioterapii, takiej jak $\mathrm{w}$ ostrej białaczce limfoblastycznej (ALL, acute lymphoblastic leukemia) z profilaktyką zajęcia ośrodkowego układu nerwowego (OUN) i następową konsolidacją allo-HSCT $[4,26]$.

\section{Przewlekłe choroby limfoproliferacyjne $\mathrm{z}$ komórek NK}

Komórki NK stanowią około $10 \%$ wszystkich limfocytów krwi obwodowej. Komórki NK pochodzą ze szpiku i mają wspólną komórkę progenitorową $z$ limfocytami $\mathrm{T}$. W przeciwieństwie do limfocytów T i B rearanżacja genów nie jest niezbędna do ich różnicowania oraz funkcjonowania. Komórki NK spełniają ważną rolę w rozpoczęciu odpowiedzi odpornościowej, przede wszystkim przez szybkie wydzielanie interferonu gamma (IFN $\gamma$ ) oraz innych cytokin niezbędnych w odpowiedzi na zakażenie bakteryjne, wirusowe czy parazytologiczne $[1,3$, $4,7,26,68]$.

Przewlekłe choroby limfoproliferacyjne komórek NK mają charakter indolentny o dobrym rokowaniu. Charakteryzują się zwiększoną liczbą krążących komórek NK. Ich średnia liczba wynosi 2,3 G/1. Przebieg choroby może być bezobjawowy i wtedy często określa się ją jako reaktywną lub lagodną przetrwałą limfocytozę NK towarzyszącą infekcjom wirusowym i chorobom tkanki łącznej [4, 17, 19, 86]. Jednak reaktywna limfocytoza NK nie powinna trwać dłużej niż 4-6 miesięcy. Jeśli populacja komórek NK we krwi obwodowej utrzymuje się dłużej niż 6 miesięcy, to mówi się o przewlekłej białaczce NK [17]. Przewlekła białaczka NK może się manifestować objawami ogólnymi, powiększeniem wątroby i śledziony lub zajęciem szpiku. Neutropenia i niedokrwistość występują jednak znacznie rzadziej niż w białaczce T-LGL i nie są tak głębokie [87]. Diagnostyka przewlekłej białaczki NK jest trudna $z$ powodu braku markera klonalnych komórek NK [1]. Komórki przewlekłej białaczki/przetrwałej limfocytozy reaktywnej NK-LGL wykazują ekspresję antygenów $\mathrm{CD} 2+\mathrm{CD} 16+\mathrm{CD} 56+$, brakuje ekspresji CD3, a antygen CD57 występuje ze zmienną częstością [17, 87]. U pacjentów $z$ przewlekłą białaczką NK-LGL opisano ponadto zmienioną ekspresję trzech rodzin receptorów związanych $z$ komórkami NK, receptorów KIR, typu C i receptorów NK [60, 88, 89]. Panel przeciwciał przeciw tym receptorom mógłby być bardzo użyteczny w diagnostyce różnicowej przewlekłej białaczki NK i reaktywnej limfocytozy NK.

Leczenie chorych na przewlekłą białaczkę NK-LGL jest takie samo jak w przypadku białaczki T-LGL; w I linii stosuje się leki immunosupresyjne $[4,26]$.

Agresywna białaczka NK-LGL jest gwałtownie przebiegającą chorobą o złym rokowaniu. Występuje u młodszych pacjentów, najczęściej pochodzenia azjatyckiego; średni wiek to 39 lat [17, 19, 90]. Jest wyróżniona jako osobna jednostka chorobowa w klasyfikacji WHO i stanowi około $10 \%$ wszystkich nowotworów LGL $[2,17]$. W patogenezie białaczki NK-LGL, zwłaszcza jej postaci agresywnej, najprawdopodobniej bierze udział wirus Epstein-Barr (EBV, Epstein-Barr virus), co może sugerować, że jest to białaczkowy wariant bardziej powszechnego chłoniaka T/NK typu nosowego [91, 92]. W obrazie klinicznym dominują objawy ogólne, hepatosplenomegalia i cytopenie we krwi obwodowej. Mogą wystąpić zaburzenia krzepnięcia pod postacią zespołu rozsianego krzepnięcia wewnątrznaczyniowego (DIC, disseminated intravascular coagulation) i niewydolność wielonarządowa [26, 92], a niekiedy zespół hemofagocytowy [7, 93]. W badaniu immunofenotypowym metodą cytometrii przepływowej większość komórek wykazuje ekspresję antygenów NK, tj. CD2+CD56+, nie wykazuje natomiast ekspresji antygenów limfocytów T, takich jak CD3 i CD57 ani rearanżacji genów TCR [1]. Najczęstsze chromosomalne aberracje w białaczce NK-LGL to delecja 6q21-q25 i 17p13, ale opisano również chorych ze złożonym kariotypem [94-96].

Standardowe leczenie według schematu CHOP jest mało skuteczne. Intensywne leczenie, takie jak $\mathrm{w}$ ALL, $\mathrm{z}$ profilaktyką zajęcia OUN, powinno być stosowane w indukcji, a w konsolidacji należy rozważyć allo-HSCT [93, 97].

\section{Podsumowanie}

Białaczki T/NK-LGL, choć występują rzadko, to stanowią duze wyzwanie dla klinicysty. W obrazie 
klinicznym dominują głębokie cytopenie, zwłaszcza neutropenia $z$ powikłaniami infekcyjnymi, wspólistniejące choroby autoimmunizacyjne, a stosowanie mało specyficznych leków immunosupresyjnych powoduje, że leczenie bywa często nieskuteczne. Mała liczba chorych utrudnia przeprowadzenie badań klinicznych, co jest przyczyną problemów $z$ opracowaniem rekomendacji dotyczących postępowania w tych schorzeniach. Postęp w badaniach nad T/NK-LGL, a zwłaszcza poznanie zaburzeń w wewnątrzkomórkowych szlakach sygnałowych, daje szansę na rozwój terapii celowanych, które wydają się jedyną nadzieją na skuteczne leczenie pacjentów $\mathrm{z}$ tymi białaczkami.

\section{Piśmiennictwo}

1. Sokol L., Loughran T.P. Large granular lymphocyte leukemia. Oncologist 2006; 11: 263-273.

2. Chan W.C., Foucar K., Morice W.G., Catovsky D. T-cell large granular lymphocyte leukemia. W: Swerdlow S.H., Campo E., Harris N.L. i wsp. (red.). World Health Organization classification of tumors. Pathology and genetics of tumours of hematopoietic and lymphoid tissues. IARC Press, Lyon 2008: 272-273.

3. O'Malley D.P. T-cell large granular leukemia and related proliferations. Am. J. Clin. Pathol. 2007; 127: 850-859.

4. Todd J.A., Sokol L. Diseases of large granular lymphocytes. Cancer Control 2007; 14: 141-150.

5. Holm A.M., Tjonnfjord G., Yndestad A. i wsp. Polyclonal expansion of large granular lymphocytes in common variable immunodeficiency - association with neutropenia. Clin. Exp. Immunol. 2006; 144: 418-424.

6. Roden A.C., Morice W.G., Hanson C.A. Immunophenotypic attributes of benign peripheral blood gammadelta $\mathrm{T}$ cells and conditions associated with their increase. Arch. Pathol. Lab. Med. 2008; 132: 1774-1780.

7. Rose M.G., Berliner N. T-cell large granular lymphocyte leukemia and related disorders. Oncologist 2004; 9: 247-258.

8. Wong K.F., Chan J.C., Liu H.S., Man C., Kwong Y.L. Chromosomal abnormalities in T-cell large granular lymphocyte leukaemia: report of two cases and review of the literature. Br. J. Haematol. 2002; 116: 598-600.

9. Gorochov G., Debre P., Leblond V. i wsp. Oligoclonal expansion of CD8+CD57+ T cells with restricted T-cell receptor beta chain variability after bone marrow transplantation. Blood 1994; 83: 587-595.

10. Halwani F., Guttmann R.D., Ste-Croix H., Prud'homme G.J. Identification of natural suppressor cells in long-term renal allograft recipients. Transplantation 1992; 54: 973-977.

11. Schwab R., Szabo P., Manavalan J.S. i wsp. Expanded CD4+ and CD8+ T cell clones in elderly humans. J. Immunol. 1997; 158: 4493-4499.

12. Smith P.R., Cavenagh J.D., Milne T. i wsp. Benign monoclonal expansion of CD8+ lymphocytes in HIV infection. J. Clin. Pathol. 2000; 53: 177-181.

13. Posnett D.N., Sinha R., Kabak S., Russo C. Clonal populations of $\mathrm{T}$ cells in normal elderly humans: the T-cell equivalent to "benign monoclonal gammapathy”. J. Exp. Med. 1994; 179: 609-618.

14. Lundell R., Hartung L., Hill S., Perkins S.L., Bahler D.W. T-cell large granular lymphocyte leukemias have multiple phenotypic abnormalities involving pan-T-cell antigens and receptors for MHC molecules. Am. J. Clin. Pathol. 2005; 124: 937-946.

15. Beck R.C., Stahl S., O'Keefe C.L i wsp. Detection of mature T-cell leukemias by flow cytometry using antiiT-cell receptor $\mathrm{V} \beta$ antibodies. Am. J. Clin. Pathol. 2003; 120: 785-794.

16. Dhodapkar M.V., Li C.Y., Lust J.A., Tefferi A., Phyliky R.L. Clinical spectrum of clonal proliferations of T-large granular lymphocytes: a T-cell clonopathy of undetermined significance? Blood 1994; 84: 1620-1627.

17. Loughran T.P. Jr, Kadin M.E., Starkebaum G. i wsp. Leukemia of large granular lymphocytes: association with clonal chromosomal abnormalities and autoimmune neutropenia, thrombocytopenia, and hemolytic anemia. Ann. Intern. Med. 1985; 102: 169-175.

18. Lamy T., Loughran T.P. Jr Clinical features of large granular lymphocyte leukemia. Semin. Hematol. 2003; 40: 185-195.

19. Loughran T.P. Jr Clonal diseases of large granular lymphocytes. Blood 1993; 82: 1-14.

20. Bareau B., Rey J., Hamidou M. i wsp. Analysis of a French cohort of patients with large granular lymphocyte leukemia: a report on 229 cases. Haematologica 2010; 95: 1534-1541.

21. Herling M., Khoury J.D., Washington L.T. i wsp. A systematic approach to diagnosis of mature T-cell leukemias reveals heterogeneity among WHO categories. Blood 2004; 104: 328-335.

22. Epling-Burnette P.K., Loughran T.P. Jr Survival signals in leukemic large granular lymphocytes. Semin. Hematol. 2003; 40: 213-220.

23. Loughran T.P. Jr, Hadlock K.G., Perzova R. i wsp. Epitope mapping of HTLV envelope seroreactivity in LGL leukaemia. Br. J. Haematol. 1998; 101: 318-324.

24. Sokol L., Agrawal D., Loughran T.P. Jr Characterization of HTLV envelope seroreactivity in large granular lymphocyte leukemia. Leuk. Res. 2005; 29: 381-387.

25. Loughran T.P. Jr, Hadlock K.G., Yang Q. i wsp. Seroreactivity to an envelope protein of human T-cell leukemia/lymphoma virus in patients with CD3 - (natural killer) lymphoproliferative disease of granular lymphocytes. Blood 1997; 90: 1977-1981.

26. Alekshun T.J., Sokol L. Diseases of large granular lymphocytes. Cancer Control 2007; 14: 141-150.

27. Zhang D., Loughran T.P. Jr Large granular lymphocytic leukemia: molecular pathogenesis, clinical manifestations, and treatment. Hematology Am. Soc. Hematol. Educ. Program 2012; 2012: 652-659.

28. Takeda K., Kaisho T., Yoshida N. i wsp. Stat3 activation is responsible for IL-6-dependent T-cell proliferation through preventing apoptosis: generation and characterization of T-cell specific Stat3-deficient mice. J. Immunol. 1998; 161: 4652-4660.

29. Koskela H.L.M., Eldfors S., Ellonen P. i wsp. Somatic STAT3 mutations in large granular lymphocytic leukemia. N. Engl. J. Med. 2012; 366: 1905-1913.

30. Andersson E.I., Rajala H.L.M., Eldfors S. i wsp. Novel somatic mutations in large granular lymphocytic leukemia affecting the STAT-pathway and T-cell activation. Blood Cancer J. 2013; 3: e168. doi:10.1038/bcj.2013.65.

31. Hayakawa F., Sugimoto K., Kurahashi S., Sumida T., Naoe T. A novel STAT3 inhibitor OPB-31121 induces tumor-specific growth inhibition in a wide range of hematopoietic malignancies without growth suppression of normal hematopoietic cells. Blood 2011; 118: abstrakt 577 .

32. Yang J., Epling-Burnette P.K., Painter J.S. i wsp. Antigen activation and impaired Fas-induced death-inducing signaling complex formation in T-large-granular lymphocyte leukemia. Blood 2008; 111: $1610-1616$.

33. Liu J.H., Wei S., Lamy T. i wsp. Blockade of Fas-dependent apoptosis by soluble Fas in LGL leukemia. Blood 2002; 100: 1449-1453. 
34. Hodge D.L., Yang J., Buschman M.D. i wsp. Interleukin-15 enhances proteasomal degradation of bid in normal lymphocytes: implications for large granular lymphocyte leukemias. Cancer Res. 2009; 69: 3986-3994.

35. Chen J., Petrus M., Bamford R. i wsp. Increased serum soluble IL-15Ralpha levels in T-cell large granular lymphocyte leukemia. Blood 2012; 119: 137-143.

36. Yang J., Liu X., Nyland S.B. i wsp. Platelet-derived growth factor mediates survival of leukemic large granular lymphocytes via an autocrine regulatory pathway. Blood 2010; 115: 51-60.

37. Kothapalli R., Kusmartseva I., Loughran T.P. Characterization of a human sphingosine-1-phosphate receptor gene (S1P5) and its differential expression in LGL leukemia. Biochim. Biophys. Acta 2002; 1579: 117-123.

38. Semenzato G., Zambello R., Starkebaum G., Oshimi K., Loughran J.P. Jr The lymphoproliferative disease of granular lymphocytes: updated criteria for diagnosis. Blood 1997; 89: 256-260.

39. Prochorec-Sobieszek M. Charakterystyka proliferacji z dużych ziarnistych limfocytów T. J. Trans. Med. 2009; 3: 81-136.

40. Mohan S.R., Maciejewski J.P. Diagnosis and therapy of neutropenia in large granular lymphocyte leukemia. Curr. Opin. Hematol. 2009; 16: 27-34.

41. Lamy T., Loughran T.P. Jr How I treat LGL leukemia? Blood 2011; 117: 2764-2774.

42. Zambello R., Semenzato G. Large granular lymphocytosis. Haematologica 1998; 83: 936-942.

43. Liu X., Loughran T.P. Jr The spectrum of large granular lymphocyte leukemia and Felty's syndrome. Curr. Opin. Hematol. 2011; 18: 254-259.

44. Prochorec-Sobieszek M., Wagner T., Maryniak R.K. Zespó1 Felty'ego i białaczka $z$ dużych ziarnistych limfocytów T — podobieństwa i różnice. Reumatologia 2007; 45: 85-91.

45. Iglesias A.L., Sifuentes Giraldo W.A., Bachiller Corral J. i wsp. Large granular lymphocyte leukemia as a complication of rheumatoid arthritis. Reumatol. Clin. 2012; 8: 365-367.

46. Kwong Y.L., Wong K.F. Association of pure red cell aplasia with T large granular lymphocyte leukaemia. J. Clin. Pathol. 1998; 51: 672-675.

47. Go R.S., Li C.Y., Tefferi A., Phyliky R.L. Acquired pure red cell aplasia associated with lymphoproliferative disease of granular T lymphocytes. Blood 2001; 98: 483-485.

48. Masuda M., Arai Y., Okamura T., Wada M., Mizoguchi H. Pure red cell aplasia (PRCA) with thymoma: a possible distinct clinical entity distinct from large granular lymphocyte (LGL) leukemia. Am. J. Hematol. 2000; 63: 102-107.

49. Kondo H., Mori A., Watanabe J. i wsp. Pure red cell aplasia associated with parvovirus B19 infection in T-large granular lymphocyte leukemia. Leuk. Lymphoma 2001; 42: 1439$-1443$.

50. Go R.S., Tefferi A., Li C.Y., Lust J.A., Phyliky R.L. Lymphoproliferative disease of granular T lymphocytes presenting as aplastic anemia. Blood 2000; 96: 3644-3646.

51. Saunthararajah Y., Molldrem J.L., Rivera M. i wsp. Coincident myelodysplastic syndrome and T-cell large granular lymphocytic disease: clinical and pathophysiological features. Br. J. Haematol. 2001; 112: 195-200.

52. Papadaki T., Stamatopoulos K., Kosmas C. i wsp. Clonal T-large granular lymphocyte proliferations associated with clonal B cell lymphoproliferative disorders: report of eight cases. Leukemia 2002; 16: 2167-2169.

53. Lima M., Goncalves C., Marques L. i wsp. Association of CD4+/ /CD56+/CD57+/CD8+(dim) large granular lymphocytic leukemia, splenic B-cell lymphoma with circulating villous lymphocytes, and idiopathic erythrocytosis. Ann. Hematol. 2001; 80: 685-690.

54. Kingreen D., Dalal B.I., Heyman M. i wsp. Lymphocytosis of large granular lymphocytes in patients with Hodgkin's disease. Am. J. Hematol. 1995; 50: 234-236.

55. Volkheimer A.D., Weinberg J.B., Beasley B.E. i wsp. Progressive immunoglobulin gene mutations in chronic lymphocytic leukemia: evidence for antigen-driven intraclonal diversification. Blood 2007; 109: 1559-1567.

56. Evans H.L., Burks E., Viswanatha D., Larson R.S. Utility of immunohistochemistry in bone marrow evaluation of T-lineage large granular lymphocyte leukemia. Hum. Pathol. 2000; 31: 1266-1273.

57. Morice W.G., Kurtin P.J., Tefferi A., Hanson C.A. Distinct bone marrow findings in T-cell granular lymphocytic leukemia revealed by paraffin section immunoperoxidase stains for CD8, TIA-1, and granzyme B. Blood 2002; 99: 268-274.

58. Osuji N., Beiske K., Randen U. i wsp. Characteristic appearances of the bone marrow in T-cell large granular lymphocyte leukaemia. Histopathology 2007; 50: 547-554.

59. Morice W.G., Kurtin P.J., Leibson P.J., Tefferi A., Hanson C.A. Demonstration of aberrant T-cell and natural killer-cell antigen expression in all cases of granular lymphocytic leukaemia. Br. J. Haematol. 2003; 120: 1026-1036.

60. Gorczyca W., Weisberger J., Liu Z. i wsp. An approach to diagnosis of T-cell lymphoproliferative disorders by flow cytometry. Cytometry 2002; 50: 177-190.

61. Melenhorst J.J., Brummendorf T.H., Kirby M., Lansdorp P.M., Barrett A.J. CD8+ T cells in large granular lymphocyte leukemia are not defective in activation- and replication-related apoptosis. Leuk. Res. 2001; 25: 699-708.

62. Wong K.F., Chan J.C., Liu H.S., Man C., Kwong Y.L. Chromosomal abnormalities in T-cell large granular lymphocyte leukaemia: report of two cases and review of the literature. Br. J. Haematol. 2002; 116: 598-600.

63. Hodges E., Krishna M.T., Pickard C., Smith J.L. Diagnostic role of tests for T-cell receptor (TCR) genes. J. Clin. Pathol. 2003; 56: 1-11.

64. Nadel B., Feeney A.J. Nucleotide deletion and P addition in V(D) $\mathrm{J}$ recombination: a determinant role of the coding-end sequence. Mol. Cell. Biol. 1997; 17: 3768-3778.

65. Davey M.P., Starkebaum G., Loughran T.P. Jr CD3+ leukemic large granular lymphocytes utilize diverse T-cell receptor V beta genes. Blood 1995; 85: 146-150.

66. Fischer L., Hummel M., Burmeister T., Schwartz S., Thiel E. Skewed expression of natural-killer (NK)-associated antigens on lymphoproliferations of large granular lymphocytes (LGL). Hematol. Oncol. 2006; 24: 78-85.

67. Nowakowski G.S., Morice W.G., Phyliky R.L., Li C.Y., Tefferi A. Human leucocyte antigen class I and killer immunoglobulin-like receptor expression patterns in T-cell large granular lymphocyte leukaemia. Br. J. Haematol. 2005; 128: 490-492.

68. Biedroń M., Mazur G., Wróbel T., Kuliczkowski K. Receptory komórek NK. Adv. Clin. Exp. Med. 2003; 12: 529-535.

69. Fortune A.F., Kelly K., Sargent J. i wsp. Large granular lymphocyte leukemia: natural history and response to treatment. Leuk. Lymphoma 2010; 51: 839-845.

70. Hamidou M., Lamy T. Large granular lymphocyte proliferations: clinical and pathogenic aspects. Rev. Med. Interne 2001; 22: $452-459$. 
71. Osuji N., Matutes E., Tjonnfjord G. i wsp. T-cell large granular lymphocyte leukemia: a report on the treatment of 29 patients and a review of the literature. Cancer 2006; 107: 570-578.

72. Pawarode A., Wallace P.K., Ford L.A., Barcos M., Baer M.R. Long-term safety and efficacy of cyclosporin A therapy for T-cell large granular lymphocyte leukemia. Leuk. Lymphoma 2010; 51: 338-341.

73. Aribi A., Huh Y., Keating M. i wsp. T-cell large granular lymphocytic (T-LGL) leukemia: experience in a single institution over 8 years. Leuk. Res. 2007; 31: 939-945.

74. Costa R.O., Bellesso M., Fischer Chamone D.A. i wsp. T-cell large granular lymphocytic leukemia: treatment experience with fludarabine. Clinics 2012; 67: 745-748.

75. Sternberg A., Eagleton H., Pillai N. i wsp. Neutropenia and anaemia associated with T-cell large granular lymphocyte leukaemia responds to fludarabine with minimal toxicity. Br. J. Haematol. 2003; 120: 699-701.

76. Tse E., Chan J.C., Pang A. i wsp. Fludarabine, mitoxantrone and dexamethasone as first-line treatment for T-cell large granular lymphocyte leukemia. Leukemia 2007; 21: 2225-2226.

77. Ma S.Y., Au W.Y., Chim C.S. i wsp. Fludarabine, mitoxantrone and dexamethasone in the treatment of indolent B- and T-cell lymphoid malignancies in Chinese patients. Br. J. Haematol. 2004; 124: 754-761.

78. Rosenblum M.D., LaBelle J.L., Chang C.C. i wsp. Efficacy of alemtuzumab treatment for refractory T-cell large granular lymphocytic leukemia. Blood 2004; 103: 1969-1971.

79. Schuetzinger C., Gaiger A., Thalhammer R. i wsp. Remission of pure red cell aplasia in $\mathrm{T}$-cell receptor gammadelta-large granular lymphocyte leukemia after therapy with low-dose alemtuzumab. Leukemia 2005; 19: 2005-2008.

80. Monjanel H., Hourioux C., Arbion F. i wsp. Rapid and durable molecular response of refractory Tcell large granular lymphocyte leukemia after alemtuzumab treatment. Leuk. Res. 2010; 34: e197-e199.

81. Subbiah V., Viny A.D., Rosenblatt S. i wsp. Outcomes of splenectomy in T-cell large granular lymphocyte leukemia with splenomegaly and cytopenia. Exp. Hematol. 2008; 36: 1078-1083.

82. Cornec D., Devauchelle-Pensec V., Jousse-Joulin S. i wsp. Long-term remission of T-cell large granular lymphocyte leukemia associated with rheumatoid arthritis after rituximab therapy. Blood 2013; 122: 1583-1586.

83. Passetto Falcao R., Pinto Simoes B., Garcia A.B., Fonseca B.A., Terra Filho J. Aggressive variant of morphologically typical T large granular lymphocyte leukemia/lymphoma lacking NK cell markers. Acta Haematol. 2000; 104: 110-114.
84. Tordjman R., Macintyre E., Emile J.F. i wsp. Aggressive acute CD3+, CD56- T-cell large granular lymphocyte leukemia with two stages of maturation arrest. Leukemia 1996; 10: 1514-1519.

85. Matutes E., Wotherspoon A.C., Parker N.E. i wsp. Transformation of T-cell large granular lymphocyte leukaemia into a high-grade large T-cell lymphoma. Br. J. Haematol. 2001; 115: 801-806.

86. Zambello R., Loughran T.P. Jr, Trentin L. i wsp. Serologic and molecular evidence for a possible pathogenetic role of viral infection in CD3-negative natural killer-type lymphoproliferative disease of granular lymphocytes. Leukemia 1995; 9: 1207-1211.

87. Tefferi A., Li C.Y., Witzig T.E. i wsp. Chronic natural killer cell lymphocytosis: a descriptive clinical study. Blood 1994; 84: 2721-2725.

88. Epling-Burnette P.K., Painter J.S., Chaurasia P. i wsp. Dysregulated NK receptor expression in patients with lymphoproliferative disease of granular lymphocytes. Blood 2004; 103: 3431-3439.

89. Zambello R., Semenzato G. Natural killer receptors in patients with lymphoproliferative diseases of granular lymphocytes. Semin. Hematol. 2003; 40: 201-212.

90. Cheung M.M., Chan J.K., Wong K.F. Natural killer cell neoplasms: a distinctive group of highly aggressive lymphomas/leukemias. Semin. Hematol. 2003; 40: 221-232.

91. Hart D.N., Baker B.W., Inglis M.J. i wsp. Epstein-Barr viral DNA in acute large granular lymphocyte (natural killer) leukemic cells. Blood 1992; 79: 2116-2123.

92. Chan J.K., Sin V.C., Wong K.F. i wsp. Nonnasal lymphoma expressing the natural killer cell marker CD56: a clinicopathologic study of 49 cases of an uncommon aggressive neoplasm. Blood 1997; 89: 4501-4513.

93. Ruskova A., Thula R., Chan G. Aggressive natural killer-cell leukemia: report of five cases and review of the literature. Leuk. Lymphoma 2004; 45: 2427-2438.

94. Siu L.L., Chan J.K., Kwong Y.L. Natural killer cell malignancies: clinicopathologic and molecular features. Histol. Histopathol. 2002; 17: 539-554.

95. Wong K.F., Zhang Y.M., Chan J.K. Cytogenetic abnormalities in natural killer cell lymphoma/leukaemia - is there a consistent pattern? Leuk. Lymphoma 1999; 34: 241-250.

96. Hamaguchi H., Yamaguchi M., Nagata K. i wsp. Aggressive NK cell ymphoma/leukemia with clonal $\operatorname{der}(3) \mathrm{t}(1 ; 3)$ (q12;p25), del(6) (q13) and del(13)(q12q14). Cancer Genet. Cytogenet. 2001; 130: 150-154.

97. Okamura T., Kishimoto T., Inoue M. i wsp. Unrelated bone marrow transplantation for Epstein-Barr virus-associated T/NK-cell lymphoproliferative disease. Bone Marrow Transplant. 2003; 31: 105-111. 